\title{
Indonesian Students Intellectual Internship Overseas
}

\author{
Agus Joko Pitoyo and Kirana Putri Prastika \\ Department of Environmental Science, the Faculty of Geography, \\ Universitas Gadjah Mada, Yogyakarta
}

Correspondence: Agus Joko Pitoyo (email: aguspit@ugm.ac.id)

\begin{abstract}
Indonesia is classified as developing country which still have low level of national education. One of the way to improve the level of education happening in this era is by studying abroad. There are lot of universities in Indonesia that already establish cooperation with foreign universities. This cooperation helps Indonesia student get the accessibility to join study abroad program. This paper has two objectives. The first one is to know the development of studying abroad program conducted by Indonesian student spatially and temporarily. The second one is to know Indonesian student's perspectives about study abroad program from their level of satisfaction. This paper uses primary and secondary data to analyze this issue. This primary data was taken from questionnaire through 14 respondents and the secondary data was taken from UNESCO statistical data and news. The results of the paper show that the spatial distribution of Indonesian student international mobility varies from Asian, European, Middle Eastern, and American countries. Indonesian student tends to visit development economy countries rather than developing economy countries. According to the data collected from 14 respondents, Japan is the most visited country and also shows that the temporal development of this international mobility is growing from 2013 to 2019 . This positive development is reinforced by the high level of satisfaction according to 14 respondents. These respondents had joined 23 program and only two programs were not satisfactory for two respondents.
\end{abstract}

Keywords: education; intelectual internship; student migrant

\section{Introduction}

Each countries have different level of education. Developed economies countries tend to have higher level of education than developing economies countries. Developing economies countries have more complex problem regarding to the low level of education. Indonesia is a country located in South-East Asia and according to World Economic Situation and
Prospects (2018), Indonesia is classified as developing economies country. The low level of education in most developing economies countries does not rule out the possibility of improvement. One of the way happening in this era is by studying abroad. There are lot of universities in Indonesia that already establish cooperation with foreign universities. This cooperation helps Indonesian student get the accessibility to join study abroad program. 
In this paper, there are two main objectives. The first one is to know the development of studying abroad program conducted by Indonesian student spatially and temporarily. The second one is to know Indonesian student's perspectives about study abroad program from their level of satisfaction.

\section{Literature Review}

Education comes from Latin word, educare and educatum. Educare means to train and educatum means the act of teaching. Sir Thomas Percy Nunn was a Professor of Education and he was born in 1870 in Bristol. Once he said that;

"Education is the complete development of individuality of the child so that he can make an original contribution to human life according to the best of his capacity."

From his words, we can conclude that education is a process. What kind of process? It depends on your purpose of life. Education has various definitions since it has been a part of human's life and humans have different purpose of life.

As we witness now, education plays an important role in our life, without education, it is impossible to survive and to live. Education is not only going to school or university and learn what the teacher explains. Education is wider than that, even mother is the first teacher of a child. From this, we know that education is already started before we even start going to school. School, university, institution, and etc. are kinds of formal education.

Formal education starts from primary, secondary, high school, and last is university or higher education. Formal education plays an important role in every countries so that the governments will know exactly the condition of education in their country. Education has also become one of human development index (HDI)'s parameters. Human Development Index (HDI) is an index to measure human's progress in a region/country by people's health, education, and income (UNDP, 2018)

There are so many ways of making improvement in education system. We all notice by now the Sustainable Development Goals (SDGs) are important goals set by United Nations General Assembly in 2015. There are 17 goals and one of them is Quality Education. This has made education become an important thing in every country. The goal is to

"Ensure inclusive and quality education for all and promote lifelong learning."

\section{United Nation}

Since education has been one of SDGs, governments have put education as one of priorities to achieve better education for all. Programs are made to help this goal achieved. One of the programs is studying abroad. Studying abroad can be applied in many forms such as student exchange, conference, workshop, competition, etc.

For higher education, many universities have applied international mobility programs and opportunities for their students as a result of a great demand in global, international, and intercultural capital for graduates (Buchanan \& Widodo, 2016). This action is a process of internationalization according to Knight (2003). Kelo, et.al. (2006) explained that mobility refers to students who cross national borders due to their studies.

International student mobility is also a result of globalization. Globalization changes the higher education system. This change pushed universities to widen their activities 


\section{Outbound Internationally Mobile Students from Indonesia}

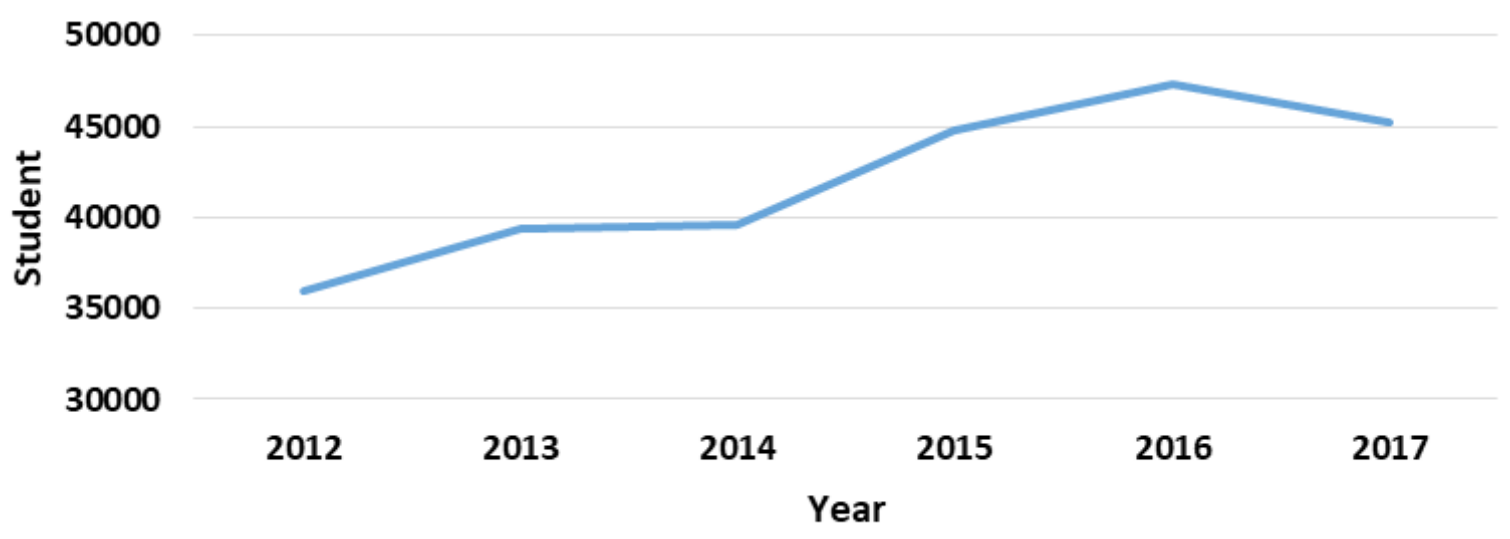

Source: UNESCO, 2019

Figure 1 Outbound Internationally Mobile Students from Indonesia

beyond national borders. Thus, students are more likely to enroll in some study abroad programs (Delgado-márquez, Hurtado-torres, \& Bondar, 2011).

Data shows that there has been a significantly growing number of international student from 0.6 million in 1975 to 3.4 million in 2009 (UNESCO, 2011). Data from UNESCO also shows number of international student from Indonesia (Figure 1). This graphs show the growing number of Indonesian international student from 2012 to 2016.

In the geography perspective, study shows factor related to the spatial mobility of international student which means from student's country of origin to destination country. International students who study in United Kingdom (UK) consider the geographical concentration of foreign students when choosing the destination country. Study shows that this condition happens in UK, but not in other countries such as United States and Australia. In general, the spatial mobility of international student is highly uneven.
Another factor influences student's option is the academic status of higher education institution or university (Findlay, 2010).

The international flow of students tends to happen from developing to developed country. Perkins \& Neumayer (2014) mentioned in their paper that in $2009,56 \%$ out of the global total international student flows were from developing to developed country. The flows from developing to developing country and developed to developed country were 18.3 $\%$ and $24.6 \%$ respectively. The flows from developed to developing country was the least of all, only about $0.9 \%$ of the global total.

\section{Methods}

In this paper, we would talk about international mobility of Indonesian students temporally and spatially. We used primary and secondary data to analyze this issue. The primary data was taken from questionnaire through 14 respondents and the secondary data was taken from UNESCO statistical 
data and news. Furthermore, we also want to know the level of satisfaction from Indonesian students after they finish study abroad. We used primary data, which was a questionnaire to 14 respondents.

\section{Discussion}

In this section, we would like to discuss the result of 14 questionnaires regarding to this topic. The respondents come from different regions and universities in Indonesia, which are Universitas Gadjah Mada (UGM), Institut Teknologi Bandung (ITB), Universitas Udayana (UNUD), Universitas Indonesia (UI), and Institut Pertanian Bogor (IPB). Their age range from 20 to 34 years old. Three of them are graduate students and the rests are undergraduate students.
The questionnaires generally ask about the spatial and temporal international mobility of respondents as students. There is 1 out of 14 who had been studying abroad 4 times, 2 out of 14 had experienced study abroad 3 times, 3 out of 14 had experienced study abroad 2 times, and 8 out of 14 had their first time studying abroad (Figure 2). The maximum questionnaire is only for 3 international mobility for each respondents. So, there are 23 international mobility of students recorded in this questionnaire. Students had different destination country of studying abroad, such as Japan, Thailand, Malaysia, South Korea, Singapore, Netherland, Sri Lanka, Taiwan, and Australia. So far, Japan had been the most visited country by our 14 respondents (Figure 3).

\section{Percentage of Respondents International Mobility Frequency as Students (\%)}

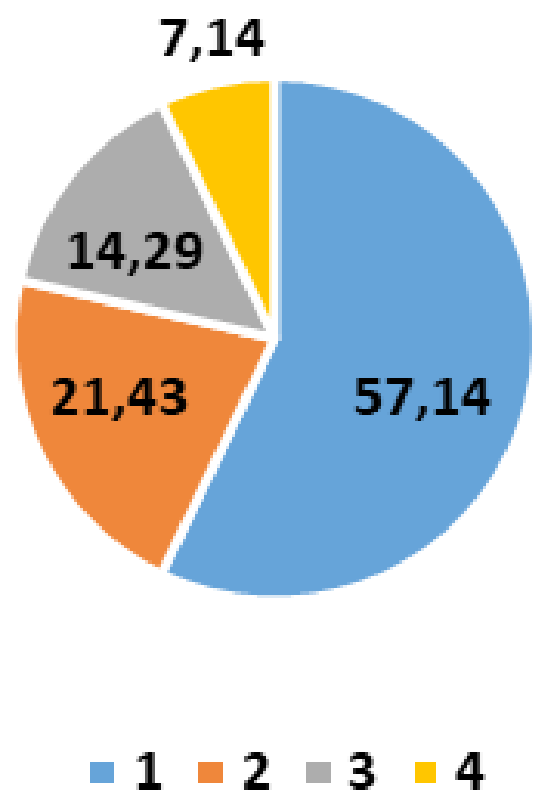

Figure 2 Percentage of Respondents International Mobility Frequency as Students 


\section{Destination Country}

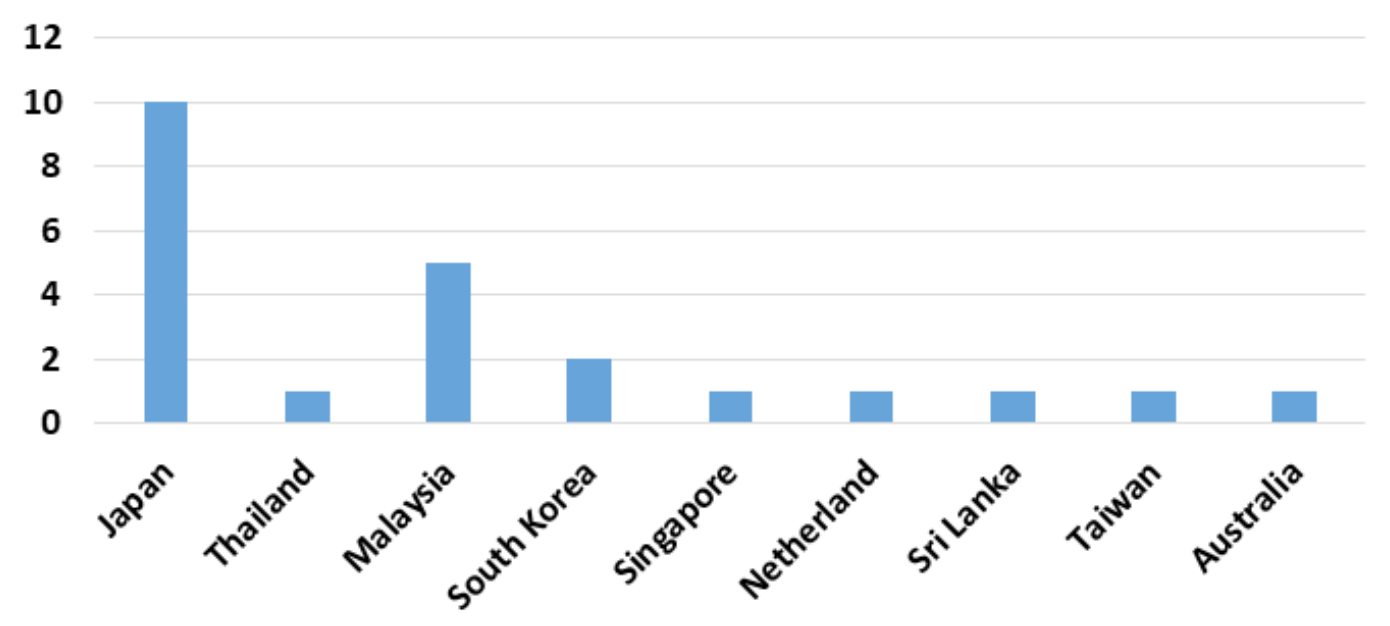

Figure 3 Destination Country Visited by Respondents

Study abroad programs mentioned in this questionnaires are exchange programs, short course, competition, conference, and MUN(Model United Nation). Based on our questionnaires result from 14 respondents, student exchange program is the most frequently done program (Figure 4). Student exchange program joined by our respondents are TWINCLE (Twin College Envoys Program) held in Japan, AISEC Global Volunteer held in Sri Lanka, and Annual Student Exchange by MacRob \& Melbourne High School held in Australia.
There are 9 respondents who had joined TWINCLE program. According to the respondents, the program held in Japan was about education and research. All of them were satisfied with the program. One respondent claimed to have problem in terms of language where there were not many Japanese who could speak English. Respondents were also asked if they would join this program again in the future. There are 7 out of 9 respondents said "yes" and the rest still hesitant to join.

\section{Number of Study Abroad Program conducted by respondents}

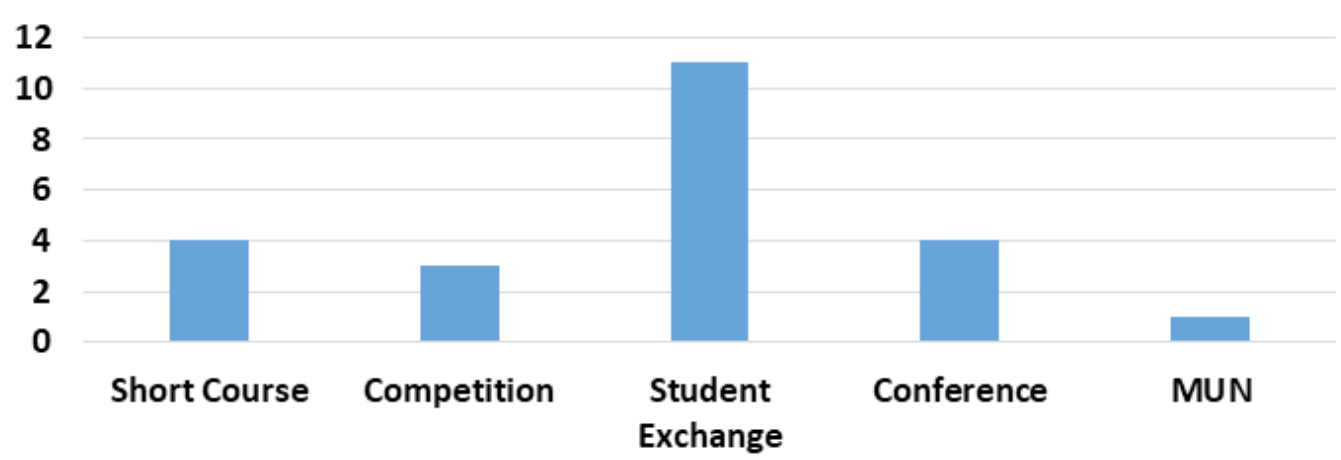

Figure 4 Number of Study Abroad Program Conducted by Respondents 
There are 1 respondent who had joined AISEC Global Volunteer program. This program was held in Sri Lanka for more than 1 month. Respondent was satisfied with the program and had no significant obstacle during the program. There are also 1 respondent who had joined Annual Student Exchange by MacRob \& Melbourne High School. This program was held in Australia for at least 6 to 14 days. Respondent also had no significant obstacle and did not hesitate to join the program again.

Student abroad program data recorded from 14 respondent shows that this program has been done since 2013 and continue to grow until 2019 (Figure 5). Most respondents started to join student abroad program since the age of 20 s for undergraduate students. There are 3 students who started to join this program since the age of 18 and 19. Graduate students started to join this program since the age of 28 and 24 years old.

Respondents were asked if they were satisfied with the program they joined. There are 23 programs listed from 14 respondents and 2 out of 23 programs or $9 \%$ were not satisfactory for respondents
(Figure 6). Those programs were Women's Empowerment through ICT Skills and Leadership UNESCO-UNITWIN in Korea and Global Goals Model United Nation in Malaysia. Respondent who joined Women's Empowerment through ICT Skills and Leadership UNESCO-UNITWIN were not satisfied with the program though the program run as expected according to respondent. Meanwhile, respondent who joined Global Goals Model United Nation were not satisfied with the program since the program did not run as expected according to respondent because there were a lot of Indonesian participants as well. From this we know that this respondent expected to meet foreign participants rather than Indonesian participants when joining study abroad program.

As in the data of UNESCO, the total of Indonesian students who are studying abroad in 2017 was 42,548 students. The most visited country was Australia with 11,040 students and Japan was in number 5 with 2,854 students (UNESCO, 2017). The figure below shows the spatial distribution of Indonesian students who study abroad (Figure 7).

\section{Number of Students Participating in Study Abroad Program per Year}

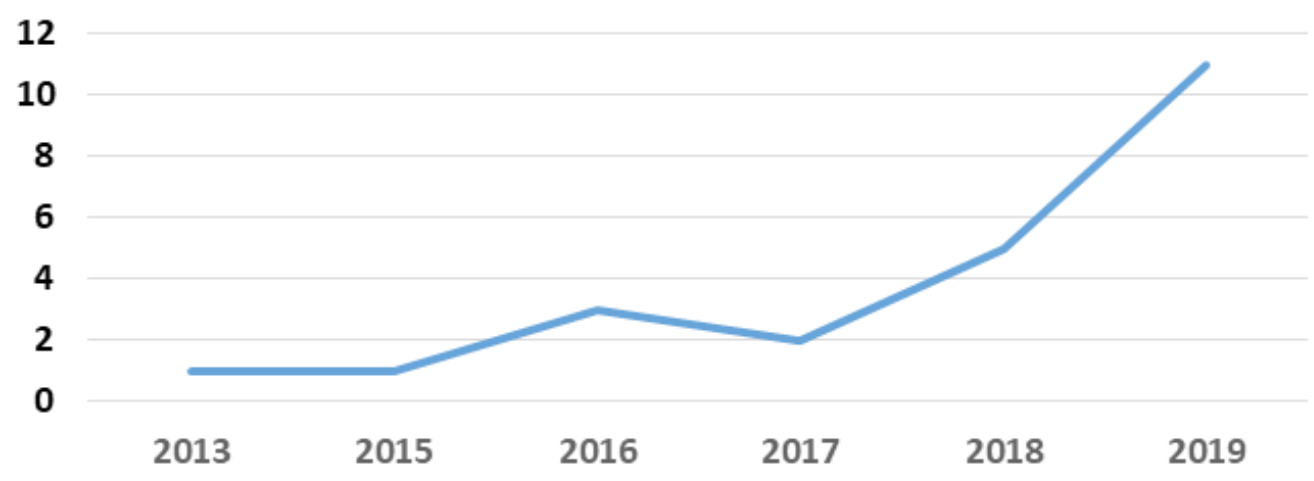

Figure 5 The Number of Students Participating in Study Abroad Program per Year based on 14 Respondents 


\section{Indonesian Student's Level of Satisfaction on Study Abroad Program (based on 14 respondents)}

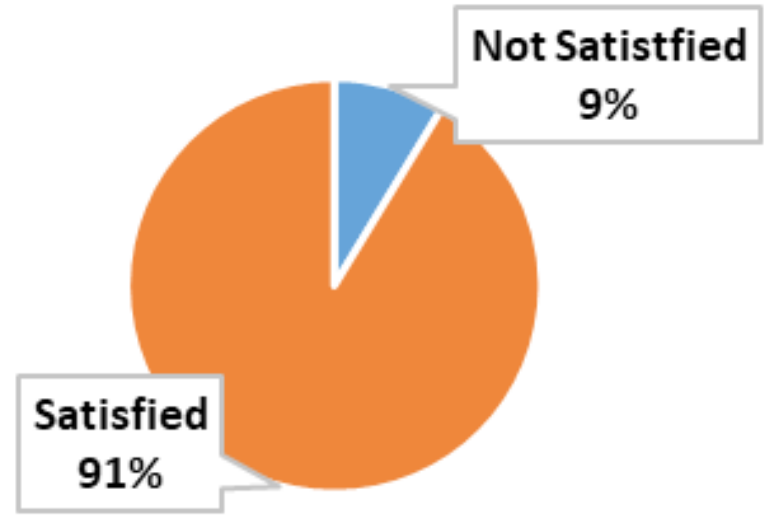

Figure 6. Indonesian Student's Level of Satisfaction on Study Abroad Program (Based on 14 Respondents)

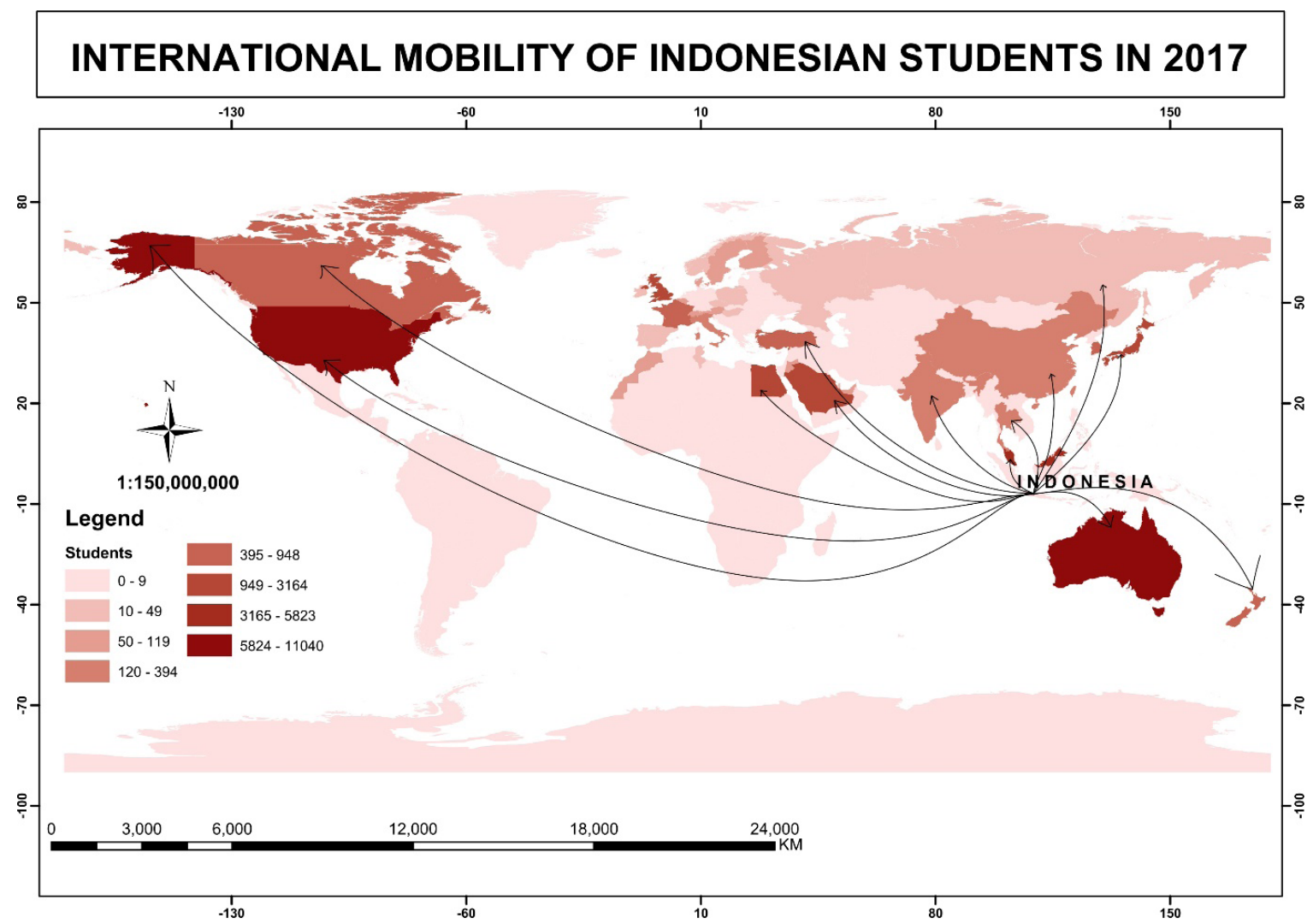

Figure 7 Map of International Mobility of Indonesian Students 
Indonesian students tend to join study abroad programs in developed economy countries than in developing economy countries except for Malaysia because this country is a neighboring country near Indonesia. Developed economy countries visited by most Indonesian student, such as Australia, United States, United Kingdom, Japan, Korea, Canada, France, New Zealand, etc. Developing economy countries visited by most Indonesian students are Egypt, India, Thailand, Morocco, etc.

\section{Conclusion and Recommendation}

The spatial distribution of Indonesian student international mobility varies from Asian, European, Middle Eastern, and American countries. Indonesian students tend to visit developed economy countries rather than developing economy countries. The top 5 most visited country by Indonesian students based on UNESCO data in 2017 were Australia, United States, Malaysia, United Kingdom, and Japan with total of all international mobility in 2017 was 42,548 students. According to the data collected from 14 respondents, Japan is the most visited country which was ranked $5^{\text {th }}$ according UNESCO data. Data also shows the temporal development of this international mobility is growing from 2012 to 2017 although there was a decline in 2017 according to UNESCO data. Data collected from 14 respondents also shows that the temporal development of this international mobility is growing from 2013 to 2019.

This positive developments is reinforced by the high level of satisfaction according to 14 respondents. These respondents had joined 23 programs and only two programs were not satisfactory for two respondents. One of the reason was because of many Indonesian students participating in the program. This showed that respondent expected to meet more foreign participants during the program rather than Indonesian participants.

From this, we know that lately Indonesia has already improved education quality through studying abroad program. Indonesian students are now able to get access to the outside national border so that they can learn more and experience more. Indonesian students should be educated about study abroad programs so that not only particular groups of students can participate in the programs. Therefore, one of the SDG which is Quality Education for all can be achieved.

\section{References}

Buchanan, J., \& Widodo, A. 2016. Your place or mine? global imbalances in internationalisation and mobilisation in educational professional experience. Asia Pacific Education Review, 17(2), 355364. https://doi.org/10.1007/s12564-0169432-y.

Delgado-márquez, B. L., Hurtado-torres, N. E., \& Bondar, Y. 2011. Internationalization in University Institutions, 8(2).

Findlay, A. M. 2010. An Assessment of Supply and Demand-side Theorizations of International Student Mobility, 49(2). $\quad$ https://doi.org/10.1111/j.14682435.2010.00643.x.

Kelo, M., Teichler, U., \& Wachter, B. (Eds.). 2006. Eurodata: Student mobility in European higher education. Bonn: Lemmens.

Knight, J. 2003. Updated internationalization definition. International Higher Education, 33, 2-3.

Perkins, R., \& Neumayer, E. 2014. Geographies of educational mobilities: Exploring the uneven flows of international students. Geographical Journal, 180(3), 246-259. https://doi.org/10.1111/geoj.12045. 
UNDP. 2018. Human Development Indices and Indicators: 2018 Statistical Update. New York: United Nation Development Programme.

UNESCO. 2011. Global Education Digest United Nations Educational, Scientific and Cultural Organization, Montreal.

UNESCO. 2019. Education: Outbound Internationally Mobile Students by host region. http://data.uis.unesco.org/index. aspx?queryid=172.

World Economic Situation and Prospects. 2018. Country Classification. https:// www.un.org/development/desa/dpad/ wp-content/uploads/sites/45/publication/ WESP2018_Full_Web-1.pdf. 